\title{
Relation between Child Labour and Aggressive Behavior among School Age Children
}

\author{
1Faten Mohammad Saad Mohammad Radwan, 1Amal M. EL-Dakhakhny, 2Shadia \\ F.Mahmoud \\ Pediatrics Nursing Department, faculty of nursing, Zagazig University \\ Psychiatric\& mental health nursing, faculty of nursing, Zagazig University
}

\begin{abstract}
Introduction: Child labor is a persistent problem throughout the world, particularly in developing countries. It is widespread in rural areas of those countries where income deficiency is widespread. It not only damages the well-being of individual children, but also slows broader national poverty decline and development efforts. The Aim of the study: This study aimed to identify the relation between child labour and aggressive behavior among school age children. Research Design: A descriptive comparative design utilize in this study. Setting: This study was conducted at 1-Industrial workshops at $\mathrm{Al}$ Bayoum village.2- three factories at $\mathrm{Al}$ Nakhas village 3- two governmental primary schools one from each village. Subjects: The subject of this study was purposive sample composed of 180 of working and school children Study tools of data collection: First tool: A structured interview questionnaire sheet, and Second tool: Aggression scale. Results: revealed that $57.8 \%$ of working children reported that helping their family was the main cause for work and $41.1 \%$ of working children were insulted and punished by their owner of work. It was found that $81.8 \%$ of working children had a high level of aggressive behavior. Conclusion: there was a statistical significant difference between both groups of working and school children regarding level of the aggressive behavior. Recommendations: All ministries and community agencies must have strict enforcement and real application of existing laws to eliminate all forms of child labour.
\end{abstract}

Key words: child Labour, aggressive, school age children

Introduction

Child labour is a far-reaching and multifaceted problem in developing countries. The types of child labour differ according to the country's beliefs and the family beliefs, rural or urban residency, socioeconomic conditions and current level of development, between other factors (Holgado et al., 2014).
According to International Trade Union Confederation [ITUC] (2016) Child labour is recognized as the worst method of abuse and exploitation of children. The Convention on rights of child (CRC) impulses, the governments to take successful measures for its eradication. Child labour is prevalent problem in developing countries. Africa and Asia account for above $90 \%$ of whole child employment. 
International Programme on the Elimination of Child Labour [IPEC] (2015) the term "child labour" is often defined as work that deprives children of their childhood, their potential and their self-esteem, and that is damaging to physical and mental development.

A recent official estimation by CAPMAS and the ILO of the number child labourers working in Egypt reveals unsavory truths; above nine percent of Egyptian children are included in child labour, which interprets to nearly 1.6 million underage workers among 5 to 17 years old. Most of them work in bad working environments, about two thirds of working children in Egypt are younger than 15 years of age with around 46 per cent among the ages of 12 and 14(Naeem, 2011).

It is important to observe that while these children are not well paid, they assist as a funder to family incomes in developing countries. The problems of education as well increase child labour and there is necessity for excellence schooling to encourage parents to refer their children to school to learn and fulfill themselves (UNICEF, 2015).

Aggressive behavior has been defined as any behavior focused towards another person that is carried out with the close intent to cause physical or psychological harm (Krahé, 2013). Empirical results recommend that aggressive children tend to form friendships with each other (Dishion and Tipsord 2011; Logis et al., 2013), they miss their social reputation, and knowledge peer refusal. When they attack and inflict harm on others, aggressive children may be seen as a danger to both victims and witnesses, who may therefore avoid interactions with them. In this method, children who engage in aggressive behavior may separate themselves from and/or become isolated by their socially proficient peers (Obsuth et al., 2015).

Nurse can play vital role in the assessment of condition in the formal and informal places to help in improving working conditions. Work places offer an entry point to offer vital health knowledge or services. Both formal and informal work places are important setting to be considered as sites for programming because each offers opportunities to read: young people. Informal workplaces are particularly important to be considered: because they may be the only point of contact with out of school or homeless young people who otherwise difficult to reach (WHO, 2017).

Aggressive behavior results from child labour can be stopped when knowledge is translated into legislation and action, moving good intention and thoughts into keeping the health of the children. The tolerance of young children is advanced and they cannot protest against discrimination. Focusing on grassroots strategies to activate communities against child labor and restoration of child workers into their homes and schools has proven vital to breaking the cycle of child labor. A multidisciplinary method comprising specialists with medical, psychological and socio-anthropological level is needed to curb this evil (Yadav\& Gowri Sengupta, 2009).

\section{Significance of the problem}

Child labour is a predominant phenomenon in Egypt. Child labour is a universal phenomenon which is considered inhumane by much international organization. All work that prevents children of their childhood and causes a mentally, physically, socially or 
ethically hazardous and harmful to them is considered a child labour. It is an essential global issue associated with poverty, insufficient educational chances, gender inequality and a variety of health risks. The likelihood that an individual will engage in aggressive or violent behaviors during the middle school increased with child labour. Hence, the present study is performed to identify the relation between child labour and aggressive behavior among school age children.

\section{Aim Of The Study}

This study aimed to identify relation between child labour and aggressive behavior among school age children.

\section{Research Question:}

Is there a relation between child labour and aggressive behavior among school age children?

\section{Subjects \& methods}

\section{Research Design}

A descriptive comparative design was used to conduct this study.

\section{Settings}

This study was conducted at 1Industrial workshops at $\mathrm{Al}$ Bayoum village.2- three factories at $\mathrm{Al}$ Nakhas village 3- two governmental primary schools one from each village.

\section{Subjects:}

The subject of this study was purposive sample composed of 180 of working and school children. 90 working children were recruited according to the the following criteria:

1-Age: group from 6- 12 years.

2- Both Sexes.

3- Working on regular basis (full time).

4- Not attending school beside work.

And 90 school children matched sample for age and sex of children from governmental primary school free from mental and physical handicap

\section{Technical design}

\section{Tools of data collection}

Data collected through used the following tools:

First tool: A structured Interviewing Sheet: The structured interview questionnaire sheet that was developed by Ismail (2008) was used in the current study and some modifications were done by the researcher. Questions number 13, 22, 28 and 98 were omitted because these questions were related to the psychosocial development in Ismail study and was not related to the aggressive behavior in the current study. It included the following parts:

Part I. Characteristics of the studied subjects

This part of the questionnaire included 19 open and closed ended questions concerned with personal data of the studied children including their age, sex, residence and their parents' educations and occupations and birth order (questions 1-19). 


\section{children:}

Part II. Data about working

This part of the questionnaire composed of 25 closed and open ended questions dealing with type of work, hours of work, rest hours, reasons for work, duration of work and training before starting (questions 20-44).

\section{Part III: data about school} children:

This part of the questionnaire consisted of 19 closed and open ended questions concerned with teaching hours, breaks, participation in recreation classes at school and hours spent at doing homework (questions 45-64).

Part IV: data about the studied children' friends, hobbies, habits and activities:

This part of the questionnaire consisted of 25 closed and open ended questions dealing with way of getting the intimate friend, having good relation with work/ school colleagues, seeing self as a good person, cheating to win, having hobbies, participating in youth club, playing with colleagues at work/ school rest, preferring team work and meal habits (questions 65-120).

\section{Second Tool: Aggression scale}

This tool was originally constructed by Mounir (1983) to assess the aggressive behavior among children. It consists of 32 items. Each child was asked to answer with "yes" or "No". Phrases are suitable for children from 612 years.

Scoring system: Items were scored 0 and one for the responses 'No' or 'Yes' respectively. The scores of the items were assumed up and the total divided by the number of items, giving a mean score of the part. The total aggression score was classified into low, moderate and high according to the following: -

$$
\begin{aligned}
& \text { Low: Score } \%<33.3 \% \\
& \text { Moderate: Score } \% 33.3 \%-66.6 \%
\end{aligned}
$$

High: Score $\%>66.6 \%$

\section{Operation design}

The operational design for this study consisted of three phases, namely preparatory phase, pilot study, and fieldwork.

\section{Preparatory Phase}

During this phase, the researcher revised local and international literature to acquire more information about the study. This also helped in modification the study tools. During this phase, the researcher also visited the selected places to get acquainted with the personnel and the study settings.

\section{Pilot Study}

A pilot study was conducted on 9 working and 9 school children to assess the applicability of the data collection tool arrangements of items estimate the time needed for each sheet and the feasibility of tools. There were no modifications were done accordingly those children were involved in the study sample.

\section{Fieldwork}

Data collection took a period of six months (four months for the studied working children and two months for school children) from June 2016 to November 2016. After receiving the 
official permission, the pilot testing of the study tools was conducted. For the studied working children, the researcher started data collection for 4 days per week (Saturday, Sunday, Tuesday, and Wednesday). From 12:00 p.m. to 6:00 p.m. on Saturday, and Sunday, and from 3:00 p.m. to 6:00 p.m. on Tuesday, and Wednesday. The researcher interviewed the working child individually and clarified the goal of the study, and obtained their verbal consent. Each working child was individually interviewed, and the questionnaire sheet tool was completed in 30 to 40 minutes according to the child age. The number of working children who attended varied between 2-4 children per day. For the school children, the researcher started the data collection for 2 days per week (Sunday and Monday), starting from 8:30 a.m. to 1:00 p.m. The researcher interviewed the students when they were on breaks included in the group and clarified the goal of the study, and obtained their verbal consent. The number of the students who attended varied between 5-6 children per day.

\section{Administrative design}

An official agreement was allowed by delivery of an official letter from the faculty of nursing to the in charge authorities of the study settings (to director of Al Nahkas primary school and to the director of $\mathrm{Al}$ Bayoum primary school ) to obtain their permission for data collection. For workshops, verbal agreements were taken from the owners of workshops and factories through personal communication after brief explanation of the study purpose.

\section{Ethical consideration}

An official agreement was allowed by submission of an official letter from the faculty of nursing to the in charge authorities of the study settings (to director of Al Nahkas primary school and to the director of $\mathrm{Al}$ Bayoum primary school ) to obtain their permission for data collection. For workshops, verbal agreements were taken from the owners of workshops and factories through personal communication after brief explanation of the study purpose.

\section{The ethical research considerations include the following:}

- The research approval was obtained from the faculty ethical committee before starting the study.

- The researcher was clarify the objectives and aim of the study to children included in the study before starting

- The researcher was assuring maintaining anonymity and confidentiality of subjects' data included in the study

- The children informed that they are permitted to select to share or not in the study and they have the freedom to draw from the study at any time.

\section{Statistical analysis}

All collected data were organized, categorized, tabulated, entered, and analyzed by using SPSS (Statistical Package for Social Sciences); a software program version 20. According to the type of data qualitative expressed as number and percentage, quantitative continues group expressed by mean $\pm \mathrm{SD}$, 
the following test was used to test differences for significance; Mont Carlo exact test. $P$ value was set at $<0.05$ for significant results \& $<0.001$ for high significant result.

\section{Results}

Table (1) shows that $51.1 \%$ of working and school children were aged between 11 to 12 years with mean age of $11.1 \pm 1.4$ years. As well as boys represented $78.9 \%$ of studied children. Concerning birth order, it was found that $43.3 \%$ of working children were the second born children in the family, while $53.3 \%$ of school children were the first. As well as $74.4 \%$ of working children compared to $96.7 \%$ of the school children living with both parents. There were a statistical significant differences between both groups regarding birth order $\left(\mathrm{P}=0.045^{*}\right)$, and child living with who $(\mathrm{P}=0.001 *)$.

Table (2) the results revealed that the highest percentage of fathers $78.9 \%$, $58.9 \%$ respectively and mothers $77.8 \%$, $52.2 \%$ respectively are aged between $40-$ 50 years with mean age of $44 \pm 6.4$ years.

Concerning fathers' level of education, it was found that $55.6 \%$ of working children' fathers were illiterate and $66.7 \%$ of school children' fathers had a university education. As regarding mothers' level of education, $73.3 \%$ of working children' mothers were illiterate while $63.3 \%$ of school children' mothers had a university education.

As regard to fathers' occupation, it was found that $74.4 \%$ of the working children' fathers were working compared to $96.7 \%$ of school children' fathers. Concerning mothers' work, it was found that $90.0 \%$ of the working children' mothers were a housewives, while $55.6 \%$ of school children' mothers were working.

Table (3) shows occupation features of the work among working children. Concerning the type of work, the result revealed that $44.4 \%$ of working children work in Carpenter' workshops and $46.7 \%$ joined by their mother to work. While $47.8 \%$ of working children started the work at age from 10 to 11 years.

As observed from the same table, $57.8 \%$ of working children report that help their family the main cause for work, and $54.4 \%$ selected this work because they had relatives or friends in the same work. Concerning causes of not attending or completing school, $62.2 \%$ of working children reported that hate the school is the main cause.

Table (4) reveals that $91.1 \%$ of working children worked for 6 days per week and took one day off per week, while $8.9 \%$ of them work for 7 days per week. By asking those children about having rest at work, $97.8 \%$ of them informed that they had rest at work, and about $88.6 \%$ of them took half an hour break every working day and $95.5 \%$ of the working children worked for 8- 10 hours per day.

As regard to the wages of working children ,it is obviously noted that $100 \%$ of the working children had wages with range from 40 to 600 pounds, and $84.4 \%$ of working children received their wages weekly

Regarding the person who received the child wages, $72.2 \%$ received their wages by themselves and $62.2 \%$ of working children gave whole wages to their families, and $35.6 \%$ gave part to family and kept part for him and $2.2 \%$ took wages for themselves. 
Table (5) presents effect of work/ study on child's behavior among the studied children. Regarding positive effect of work on behavior of the studied children, $64.4 \%$ of working children be independent, while $38.9 \%$ of school children felt being important $\left(\mathrm{P}=0.007^{*}\right)$ . In contrast, negative effect of work on behavior, $55.6 \%$ of working children was nervous, while $48.9 \%$ of school children had a bad behavior $(\mathrm{P}=0.001 *)$. . About help the family at work at day end, $58.2 \%$, and $88.3 \%$ respectively of studied group helped the family in ordering home $\left(\mathrm{P}=0.001^{*}\right)$.

Regarding reaction of owner of work/teacher of child's mistake, it was found that $41.1 \%$ of working children were insulted and punished by their owner of work, while $37.8 \%$ of school children were discussed and learn by their teacher $\left(\mathrm{P}=0.001^{*}\right)$. And about child's reaction, $58.9 \%$ of working children were annoyed, while $51.1 \%$ of school children were understood and avoid repetition $\left(\mathrm{P}=0.045^{*}\right) . \quad$ It was found that $55.6 \%$ of working children hoped to be a worker in the future, compared to $62.2 \%$ of school children hoped to be a professional worker in the future $(\mathrm{P}=0.001 *)$.

Table (6) describes that $85.6 \%$ of working children had aggressive behavior, compared to $16.7 \%$ of school children $(\mathrm{P}=0.001 *)$.

Table (7) describes level of aggressive behavior, it was found that $81.8 \%$ of aggressive working children had high level of the aggressive behavior, compared to $0 \%$ of the school children $(\mathrm{P}=0.001 *)$.

\section{Results}

Table (1): Characteristics of the studied children $(n=180)$.

\begin{tabular}{|c|c|c|c|c|c|c|}
\hline & \multirow[t]{3}{*}{ Children characteristics } & \multicolumn{4}{|c|}{ Group } & \multirow{3}{*}{ MCP } \\
\hline & & \multicolumn{2}{|c|}{$\begin{array}{c}\text { Working children } \\
(\mathbf{n}=90)\end{array}$} & \multicolumn{2}{|c|}{$\begin{array}{l}\text { School children } \\
(\mathrm{n}=90)\end{array}$} & \\
\hline & & No & $\%$ & No & $\%$ & \\
\hline \multirow[t]{3}{*}{ Age (years) } & $<10$ & 9 & $10.0 \%$ & 9 & $10.0 \%$ & 1.000 \\
\hline & $10-11$ & 35 & $38.9 \%$ & 35 & $38.9 \%$ & \\
\hline & -12 & 46 & $51.1 \%$ & 46 & $51.1 \%$ & \\
\hline Mean \pm SD & & \multicolumn{2}{|c|}{$11.1 \pm 1.4$} & \multicolumn{2}{|c|}{$11.1 \pm 1.4$} & \\
\hline \multirow[t]{2}{*}{ Gender } & Male & 71 & $78.9 \%$ & 71 & $78.9 \%$ & \\
\hline & Female & 19 & $21.1 \%$ & 19 & $21.1 \%$ & 1.000 \\
\hline \multirow[t]{5}{*}{ Birth order } & $1^{\mathrm{st}}$ & 12 & $13.3 \%$ & 48 & $53.3 \%$ & \\
\hline & $2^{\text {nd }}$ & 39 & $43.3 \%$ & 27 & $30.0 \%$ & \\
\hline & $3^{\text {rd }}$ & 28 & $31.1 \%$ & 10 & $11.1 \%$ & $0.045^{*}$ \\
\hline & $4^{\text {th }}$ & 9 & $10.0 \%$ & 4 & $4.4 \%$ & \\
\hline & $5+$ & 2 & $2.2 \%$ & 1 & $1.1 \%$ & \\
\hline \multirow[t]{4}{*}{ Living with } & Parents & 67 & $74.4 \%$ & 87 & $96.7 \%$ & \\
\hline & Only father & 4 & $4.4 \%$ & 1 & $1.1 \%$ & \\
\hline & Only mother & 19 & $21.1 \%$ & 0 & $0.0 \%$ & \\
\hline & Father and his wife & 0 & $0.0 \%$ & 2 & $2.2 \%$ & $0.001 *$ \\
\hline
\end{tabular}


Relation between Child Labour and Aggressive Behavior among School Age Children

Table (2): Parents' characteristics of the studied children $(n=180)$.

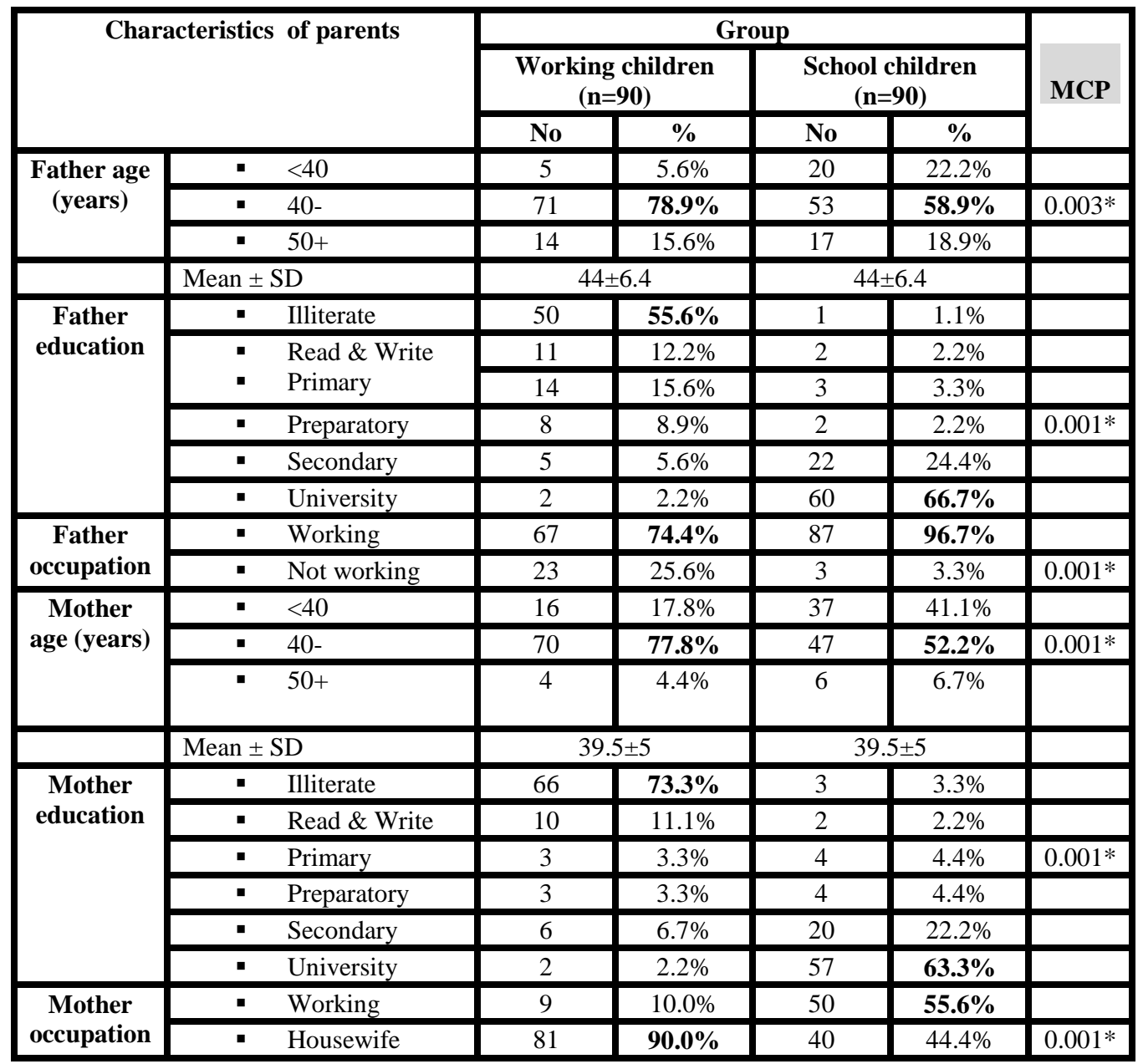

Table (3): Occupation features of the work among working children $(n=90)$.

\begin{tabular}{|c|c|c|c|}
\hline \multicolumn{2}{|r|}{ Features } & No & $\%$ \\
\hline \multirow[t]{4}{*}{ 1-Type of work } & - Work in a factory & 33 & $36.7 \%$ \\
\hline & - $\quad$ Carpentry workshops & 40 & $44.4 \%$ \\
\hline & - $\quad$ Repairing cars & 13 & $14.4 \%$ \\
\hline & - Welding & 4 & $4.4 \%$ \\
\hline \multirow[t]{3}{*}{ 2- Age at starting work } & - $6-$ & 15 & $16.7 \%$ \\
\hline & - $8-$ & 32 & $35.6 \%$ \\
\hline & - $\quad 10-11$ & 43 & $\mathbf{4 7 . 8 \%}$ \\
\hline \multirow[t]{5}{*}{ 5- Causes of working } & - $\quad$ Lack of money for school & 8 & $8.9 \%$ \\
\hline & - $\quad$ School failure & 22 & $24.4 \%$ \\
\hline & - $\quad$ Help family & 52 & $57.8 \%$ \\
\hline & - $\quad$ Help father at work & 4 & $4.4 \%$ \\
\hline & - $\quad$ Family troubles & 4 & $4.4 \%$ \\
\hline
\end{tabular}


Faten Mohammad Saad Mohammad Radwan, Amal M. EL-Dakhakhny, Shadia F.Mahmoud

Table (4): Work related data and wages among working children $(\mathrm{n}=90$.

\begin{tabular}{|c|c|c|c|}
\hline \multicolumn{2}{|c|}{ Items } & No & $\%$ \\
\hline \multirow[t]{2}{*}{ Number of working days per week } & 6 & 82 & $91.1 \%$ \\
\hline & 7 & 8 & $8.9 \%$ \\
\hline \multirow[t]{2}{*}{ Weekly day off at week } & Yes & 82 & $91.1 \%$ \\
\hline & No & 8 & $8.9 \%$ \\
\hline \multirow[t]{3}{*}{ Hours spent at work day } & - $<5$ & 0 & $0.0 \%$ \\
\hline & - $6-8$ & 4 & $4.6 \%$ \\
\hline & - $\quad 8-10$ & 84 & $95.5 \%$ \\
\hline Received wages & Yes & 90 & $100.0 \%$ \\
\hline How much & $\begin{array}{c}\text { Range } \\
\text { Mean } \pm \text { SD } \\
\text { Median }\end{array}$ & & \\
\hline Wages frequency & $\begin{array}{lc}\text { - } & \text { Daily } \\
\text { - } & \text { Weekly } \\
\text { - } & \text { Monthly }\end{array}$ & $\begin{array}{c}6 \\
76 \\
8\end{array}$ & $\begin{array}{c}6.7 \% \\
\mathbf{8 4 . 4 \%} \\
8.9 \%\end{array}$ \\
\hline
\end{tabular}

Table (5): Effect of work/ study on child's behavior among the studied children $(n=180)$.

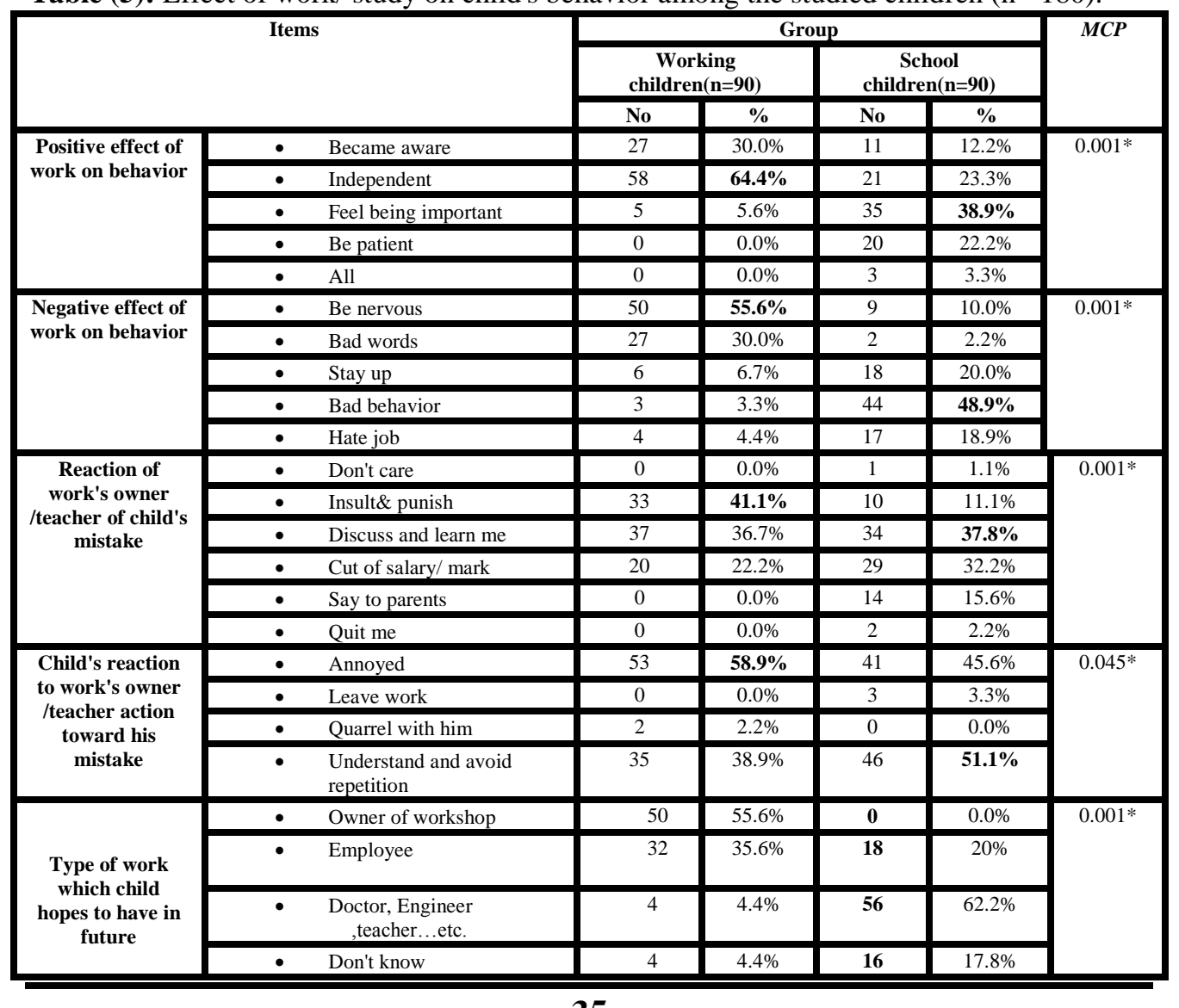


Table (6): Presence of aggressive behavior among studied children (Mounir aggression scale).

\begin{tabular}{|c|c|c|c|c|c|}
\hline \multirow{2}{*}{ Aggression } & \multicolumn{4}{|c|}{ Group } & \multirow{2}{*}{} \\
\cline { 2 - 5 } & \multicolumn{2}{|c|}{ Working children(n=90) } & \multicolumn{2}{|c|}{ School children(n=90) } & \\
\cline { 2 - 5 } & No & $\%$ & No & $\%$ & \multirow{2}{*}{ MCP } \\
\hline Aggressive behavior & & & & & \\
\hline - No & 13 & $14.4 \%$ & 75 & $\mathbf{8 3 . 3 \%}$ & $0.001^{*}$ \\
\hline Yes & 77 & $\mathbf{8 5 . 6 \%}$ & 15 & $16.7 \%$ & \\
\hline
\end{tabular}

Table (7): Level of aggressive behavior among studied children (Mounir aggression scale.

\begin{tabular}{|c|c|c|c|c|c|}
\hline \multirow{2}{*}{ Aggression } & \multicolumn{4}{|c|}{ Group } & \multirow{2}{*}{ MCP } \\
\cline { 2 - 5 } & \multicolumn{2}{|c|}{$\begin{array}{c}\text { Aggressive Working } \\
\text { children(n=77) }\end{array}$} & \multicolumn{2}{c|}{$\begin{array}{c}\text { Aggressive School } \\
\text { children(n=15) }\end{array}$} & \multirow{2}{*}{} \\
\cline { 2 - 5 } & No & $\%$ & No & & \\
\hline $\begin{array}{c}\text { Level of Aggressive } \\
\text { behavior }\end{array}$ & & & & & \\
\hline - Low & 2 & $2.6 \%$ & 5 & $33.4 \%$ & $0.001 *$ \\
\hline - Moderate & 12 & $15.6 \%$ & 10 & $66.6 \%$ & \\
\hline - High & 63 & $\mathbf{8 1 . 8 \%}$ & 0 & $0.0 \%$ & \\
\hline
\end{tabular}

\section{Discussion}

Child labour remains one of the most provocative and controversial challenges facing the world at the beginning of the 21 st century. Furthermore, child labor's close links to poverty, lack of education, poor health, and gender inequalities highlight the need for broad-based social and economic progress. The likelihood that an individual will engage in aggressive or violent behaviors during the middle school increased with child labour (Rogerro P et al, 2007).

The current study aims at shedding light on the relation between child labour and aggressive behavior among school age children, regarding characteristics of the studied children and their parents, the results of the present study clarify that more than three quarters of working children were boys. This may be justified as to the traditions and cultural believes which say that work is useful for boys' personalities' development. The findings were in agreement with Portner (2014) who conducted a study about effects of parental absence on child labour and school attendance in the Philippines and found that, the majority of working school age children was boys.

Although the Egyptian child labour law (1996) bans the employment of children who are less than 14 years of age, the result of the current study revealed that slightly more than half of working children aged from 11 to 12 years. Similar finding was reached by Masoud (2010) who studied the impact of child labour on psychosocial development of under fourteen years in Assiut city, Egypt, who found the 
majority of working children were ages between 10 to 12 years.

Regarding birth order, slightly less than half of working children in the present study were the second child, while slightly more than half of school children in the present study were the first child (table 1). It may be justified as parents usually intend to educate their oldest child as he is usually surrounded by special care and attention. The findings were in agreement with Ismail et al, (2008) who studied the impact of children labour on psychosocial development of school age children in Ismalia Governorate, who found that more than half of working school age children was the third and more.

The findings of the current study clarified that three quarters of working children living with both parents, while almost all the school children living with their parents. This result is consistent with Soliman (2003) who studied the community based survey of injury among children under 16 years in a rural area in Ismailia governorate and Ismail et al, (2008), who found that the highest percentage of children lived with both parents.

Abd El-Daiem (2009) who studied the aggressive behavior among working and non-working school age children at Shubrament village- Giza Governorate, reported that parents of working children had low awareness of the importance of education and this pushes children to child labour. This matches with the result of the present study where more than half of fathers and about three quarters of mothers of working children were illiterate, while more than two third of fathers and about two third of mothers of school children had university education. This result explained that the higher rate of illiteracy shows the ignorance of parents which is a supply factor and contributory cause of child labour. This result also supported by Pasdar (2014) who studied nutritional status of working children as a neglected group in Kermanshah, who found that more than two thirds of fathers and more than three quarters of mothers of working children were illiterate.

Concerning father's occupation, about three quarters of working children' fathers and almost all school children' fathers were working. This finding is contradicted with Abd El-Daiem (2009) who reported that less than half of fathers of working and non- working school age children had private work.

The present study clarified that the majority of working children' mothers were a housewives, while more than half of school children' mothers were working. This result is contradicted with Ismail et al, (2008), who found the highest percentage of mothers of working and school children were a housewives.

Regarding type of work, the findings of the study showed that less than half of working children work in carpentey workshops. This result was contradicted with Abd El-Daiem (2009), who found that the majority of working children work in manual skills (hand crafts). Also more than half of working children selected this work because they had relatives or friends in the same work. This result was supported by Ismail et al, (2008), who found that more than half of boys and all of girls work in agricultural fields, perhaps because working children had friends or relatives in the same work.

Kotb (2011) who studied the agricultural labour among school children in rural Assiut, Egypt, reported that more 
than two thirds of working children started the work below age of 10 years. This result was contradicted with the present study found that less than half of working children started the work at age from 10 to 11 years.

Regarding the main cause for work, the present study revealed that more than half of working children work to help their family. This result was consistent with Kotb (2011) who found that more than three quarters of working children work to help the father and share in the family in expenses. Also Munubi (2013) who studied assessment of the causes and effects of domestic child labor and its impacts on society: A case study of Aar Es Salaam- Tanzania, who found that all working children were engaged in working for the purpose of increasing and supporting family income.

The results of the present study revealed that the majority of working children worked for 6 days per week and took one day off per week, this result was in accordance with Etiler et al (2011) who studied the effect of labour on physical growth of children: Comparison of the results of two studies conducted in Izmit, who found all working children worked for 6 days a week. This may be explained by children should have a day for rest as the Egyptian Child Right (1989) which assured that children should not work at the weekends to rest themselves.

Regarding working hours, the majority of working children worked 8 to 10 hours per day; this finding was supported by Ahmad (2012) who conducted a study about poverty, education and child labour in Aligarh city-India, who found the majority of child workers work for 12 to 14 hours a day. Also Kiani (2010), who studied a significant Impact of Child Labor on
Pakistan's Economy, found that half of child labourers worked more than 56 hours per week. The researcher was surprised to note that none of working children had normal working hours of less than four hours a day. As per the law, children should not work for longer hours. But in practice the law was not strictly followed.

As regard to the wages of working children, it is obviously noted that all working children had wages with range from 40 to 600 pounds, and more than three quarters of working children received their wages weekly. This result was consistent with Abdel Raouf et al (2011) who studied child labour in Egypt, who reported that the majority of working children received more than 250 pounds and the highest percentage of them received weekly wages.

As regards the cause of injury, less than half of working children were injured by sharp work instruments. These findings is agreed with Shteiwi et al (2016) who reported about national child labour survey 2016 of Jordan, who found less than one fifth of working children were injured by a dangerous tools due to work place conditions. These may be because of hazardous working conditions that caused by unhealthy work environment, unsafe equipment or heavy loads and dangerous work locations. This assured that labour effects children body directly or indirectly. Also Schnitzer (2006) who studied the prevention of unintentional childhood injuries mentioned that the type of injuries and the circumstances surrounding children were the most cause of death and disability of children.

Regarding positive effect of work on behavior, the results of the present study revealed that more than two third of working children became independent, 
compared to more than one third of school children felt being important. It may be due to working children received wages and felt responsible toward their families, while school children seen themselves as a good citizen because of their education. This result is agreed with Mohamed et al (2009) who found that working children experience positive effect of their work as they are selfdependent and earning money.

On the other hand, the results of the present study revealed that more than half of working children experience negative effect of work on behavior, as they were nervous, while more than one third of school children had a bad behavior. This was agreed with Masoud (2010) who found that the higher percent of those children felt tired, were nervous and learned bad behavior or language. This result was congruent with Islam\& Choe (2013) who studied child labor and schooling responses to access to microcredit in rural Bangladesh concluded that may be due to ageappropriate tasks that did not present hazards and not interfere with child's schooling could been a normal part of healthy growing of children.

Abd El-Daiem (2009) found that about three quarters of working children complain of insulting and corporal punishment as this was the main way of owner of work to manage working child's mistake. This finding was supported the present study finding that less than half of working children were insulted and punished by their owner of work compared less than one fifth of school children were insulted and punished by their teacher.

It was found that the highest percentage of working children had aggressive behavior, compared to the highest percentage of school children did not have aggressive behavior table. This may explained to situational difficulties faced by working children more than school children that trigger aggressive behavior in children. This result was gone in the same line with Abd El-Daiem (2009) who stated that there was things triggers aggressive behavior in children including physical fear of others, emotional trauma and family difficulties. Also Anderson (2005) who studied video games and aggressive thoughts, feelings and behavior in the laboratory and in life, found that situational factors like expected and non- expected frustration was a major cause of aggression.

Hamdouna (2011) who studied psychosocial characters of street working children in the Northern Part of the Gaza strip; Comparative study, who found the both group of working and non-working children had a high level of aggression. This result was agreed with the present study as it found that more than three quarters of working children reported high level of the aggressive behavior

\section{Conclusion}

Based upon findings of the present study, it can be concluded that working children have a high level of the aggressive behavior $(\mathrm{P}=0.001 *)$.

\section{Recommendation}

- Increase social awareness about causes and negative effects of labour on children through the mass media

- Educational program to parents about consequences of child labour and guide parent about the importance of education for their children and using family planning methods. 
- School nurse must share in early detection of pupils who dislike school and manage their problems and cooperate with teachers and parents in management and follow up of learning problems as well as counseling of children and parents.

- Further studies on the relationship between children labour and other behavior problems

- Studies to detect the long term effect of child labour on school age problem.

\section{References}

Abd El- Daiem NA, El Karmalawy EM and El-Shaer EH (2009): Aggressive behavior among working and nonworking school age children at Shubrament village - Giza, Governorate, faculty of nursing, Cairo University.

Abdel Raouf NM, Abdel Aziz NA, Hassan NE\& Samir RS (2011): Child Labor in Egypt. Department of Statistics- English Section, Faculty of Economics and Political Science. Cairo University.

Ahmad A (2012): Poverty, Education and Child Labour in Aligarh city-India. Studies on Home and Community Science Journal, 6(3): 165-172.

Anderson CA \& Dill KE (2005): Video games and aggressive thoughts, feelings and behavior in the laboratory and in life. Journal of Personality and social Psychology; 4(78): PP. 772-790.

Dishion TJ\& Tipsord JM (2011): Peer contagion in child and adolescent social and emotional development. Annual Review of Psychology. 2011; 62:189-
214. doi: 10.1146/ annurev. psych. 093 008.100412 .

Etiler N, Caglayan C, Cizmecioglu FM, Yavuz CI, Hatun S \& Hamzaoglu O (2011):The effect of labour on physical growth of children: Comparison of the results of two studies conducted in Izmit.Turkish Archives of Pediatrics 2011;46: 105-10.

Hamdouna OS (2011): psychosocial Characters of street working children in the Northern Part of the Gaza strip; Comparative study.Journal of $\mathrm{Al}$ Azhar University-Gaza .Human Sciences; 13(1): PP: 1-24.

Holgado D, Maya-Jariego I, Ramos I (2014): Impact of child labor on academic performance: evidence from the program 'Edúcame Primero Colombia' International Journal of Educational Development. 34(1):5866.

doi:

10.1016/j.ijedudev.2012.08.004.

International Programme on the Elimination of Child Labour [IPEC] (2015): Paving the way to decent work for young people -Executive Summary. Available at http://www.ilo.org/ipecinfo/product/d ownload.do? type $=$ document $\&$ id $=2697$ 8.

International Trade Union Confederation [ITUC] (2016): Child labour/ forced labour. Available at http://www.ituccsi.org

Islam A \& Choe C (21013): child labor and schooling responses to access to microcredit in rural Bangladesh. Economic Inquiry, 51(1), 46-61.

Ismail A, El- Samman AG, Mahmoud S and Abo El Maty G (2008): Impact of children labor on psychosocial 
development of school age children in Ismalia Governorate. Assiut university bullying environment Research; 11(1): PP: 99-122.

Kiani AK (2010): A significant Impact of Child Labor on Pakistan's Economy; Globelics 2010, $\quad 8^{\text {th }} \quad$ International Conference: Making Innovation Work for Society: Linking, Leveraging and Learning;, University of Malaya, Kuala Lumpur, Malaysia.

Kotb SA, Mohamed AG, Abdel Khalek EM \& Yones DA (2011): Agricultural labor among school children in rural Assiut, Egypt. Life Science Journal; 8(2): PP:323-340.

Krahé B (2013): The Social Psychology of Aggression. Hove, England:

Psychology Press.

Logis HA, Rodkin PC, Gest SD\& Ahn HJ (2013): Popularity as an organizing factor of preadolescent friendship networks: Beyond prosocial and aggressive behavior. Journal of Research on Adolescence; 23(3):413-423.doi: 10.1111/jora.12033.

Masoud ES, Marzouk SA and Mahmoud SR (2010): Impact of child labor on psychosocial development of under fourteen years in Assiut city, Egypt; Al-Azhar Assiut Medical Journal: 8(3): PP: 252-278.

Mohamed SA, Mohamed AG, Abdel Khalek EM\& Younes DA (2009): Agricultural child labor among school children in Koom Abouheel village, Abnoub district, Assiut governorate .El-Minia Med Bull; 20(2) PP: $248-260$

Munubi H (2013): Assessment of the causes and effects of domestic child labor and its impacts on society: A case syudy of Aar Es Salaam- Tanzania. Journal of Global Gender Studies; 1(1) PP 1-23.

Naeem Z, Shaukat F and Ahmed Z (2011): Child labor in relation to poverty. International Journal of Health Sciences; 5(2): PP: 48-49.
Obsuth I, Eisner MP, Malti T \& Ribeaud D (2015): The developmental relation between aggressive behaviour and prosocial behaviour: A 5-year longitudinal study; BMC Pshychololgy; 3(1): P:16. doi: 10.1186/s40359-015-0073-4.

Pasdar Y, Darbandi M \& Nachvak SM (2014): Nutritional Status of Working Children as a Neglected Group in Kermanshah. Journal of Community Health Research; 3(2): PP: 124131.

Portner CC (2014): Effects of Parental Absence on Child Labor and School Attendance in the Philippines. Center for Studies in Demography and Ecology, University of Washington.

https://static1.squarespace.com/static/53c31c 5ce4b053fc7d131b18/t/540dc0b6e4b03fd14 6a88157/1410187446841/reho_2014_09.pdf

Roggero P, Mangiaterra V, Bustrea F \& Rosati F (2007): The Health Impact of Child Labor in Developing Countries: Evidence From Cross-Country Data : American Journal for Public Health ; 97(2): 271-275.

Schnitzer PG (2006): studied the prevention of unintentional childhood injuries. American family physician; 74(11):PP. 1864-1869.

Shteiwi M, Alkhatib W \& SaadEdeen A (2016): National Child Labour Survey 2016 of Jordan: Summary Report on Main Findings. Center for Strategic Studies University of Jordan. P: 37.

Soliman E (2003): community based survey of injury among children under 16 years in a rural area in Ismailia governorate, Egypt, Master thesis in pediatrics, faculty of medicine, Suez Canal University.

Unicef (2015): Child protection from violence, exploitation and abuse. Available at: https://www.unicef.org/protection/57929 child_labour.html. Accessed on 10/1/2017 on $3 \mathrm{am}$. 
Relation between Child Labour and Aggressive Behavior among School Age Children

WHO (2017): Poverty and Hazardous Child Labour: A Vicious Circle. Avaliable at: http://www.who.int/ceh/risks/labour/en/ Accessed 1/4/2017.
Yadav SK \& Gowri Sengupta G (2009): Environmental and occupational health problems of child labour: Some Issues and Challenges for Future. J Hum Ecol; 28(14):
PP:3-8. 